\title{
NEW DATA ON THE DOLINES OF VELEBIT MOUNTAIN: AN EVALUATION OF THEIR SEDIMENTARY ARCHIVE POTENTIAL IN THE RECONSTRUCTION OF LANDSCAPE EVOLUTION
}

\author{
NOVI PODATKI Z VRTAČ VELEBITA: VREDNOTENJE \\ USEDLINSKIH ARHIVSKIH MOŽNOSTI ZA REKONSTRUKCIJO \\ RAZVOJA POVRŠJA
}

\author{
Christèle BALLUT ${ }^{1} \&$ Sanja FAIVRE ${ }^{2 *}$
}

\begin{abstract}
UDC 551.435.82(497.5)

Christèle Ballut \& Sanja Faivre: New data on the dolines of Velebit Mountain: An evaluation of their sedimentary archive potential in the reconstruction of landscape evolution

The first approach to the relationships between societies and physical environments on Velebit Mountain shows narrow correlations between spatial distribution of dolines, soil formation, hydric resources, vegetation and land occupation. In 2002, sediment cores have been obtained from different dolines of Velebit Mountain to evaluate the potential of their sedimentary archives in order to reconstruct the landscape history. On the littoral slopes and on the top parts of the mountain, the dolines were difficult to dig due to the presence of rocks in depth. Nevertheless, the cores have been sampled and soil analyses have been made (physical and chemical analyses: colour, grain size, $\mathrm{pH}, \mathrm{CaCO}_{3}, \mathrm{C}, \mathrm{N}, \mathrm{P}, \mathrm{K}, \mathrm{Mg}, \mathrm{CEC}$ ). No dating materials were found. The first results attest to rather homogeneous pedologic processes in each area studied (Kamenica, Stinica, Baške Oštarije and Bilensko Mirevo), but they also indicate colluvial contributions. These contributions differ from one doline to another according to their location and morphology. Dolines reveal themselves to be not very good traps, as the representative nature of their sedimentary archives could be very local. However, the best profile has been obtained at Bilensko Mirevo, which shows a change in the soil nutrient content from an impoverishment in its middle part toward an increase of the soil nutrients in recent parts. Those environmental changes could not be precisely dated, but could be correlated with the $17^{\text {th }}$ to $20^{\text {th }}$ century phase of strong human impact on the Velebit environment and with the rural depopulation observed since the second half of the $20^{\text {th }}$ century.
\end{abstract}

Keywords: karst, dolines, Mediterranean soils, Velebit Mountain, Dinarides, Croatia.

\author{
Izvleček \\ UDK 551.435.82(497.5) \\ Christèle Ballut \& Sanja Faivre: Novi podatki z vrtač Velebita: \\ Vrednotenje usedlinskih arhivskih možnosti za rekonstrukcijo \\ razvoja površja
}

Prvi pristop k razmerjem med družbo in naravnim okoljem na Velebitu kaže ozko korelacijo med prostorsko razporeditvijo vrtač, tvorbo prsti, vodnih virov, vegetacijo ter rabo tal. Leta 2002 so bila iz različnih vrtač Velebita vzeta jedra sedimenta, da bi ovrednotili možnosti usedlinskih arhivov za rekonstrukcijo razvoja površja. Na obmorskih pobočjih in na zgornjih območjih gorovja je bilo v vrtače težko kopati, saj so bila njihova dna zapolnjena s skalami. Vseeno so bila jedra izkopana in analize prsti narejene (fizikalne in kemične analize: barva, velikost zrn, $\mathrm{pH}, \mathrm{CaCO}_{3}, \mathrm{C}, \mathrm{N}, \mathrm{P}, \mathrm{K}, \mathrm{Mg}, \mathrm{CEC}$ ). Najdenega ni bilo nobenega gradiva za datiranje. Prvi rezultati potrjujejo razmeroma homogene pedološke procese $\mathrm{v}$ posameznih proučevanih območjih (Kamenica, Stinica, Baške Oštarije in Bilensko Mirevo), kažejo pa tudi na vpliv koluvialnih procesov. Ti vplivi se sicer razlikujejo med vrtačami glede na njihovo lokacijo in morfologijo. Vrtače se niso izkazale za dobro izbiro, ker je lahko reprezentativna narava usedlinskih arhivov precej lokalna. Najboljši profil je bil narejen pri Bilenskem Mirevem, ki kaže spremembo v vsebini nutrientov v prsti od osiromašenih prsti v sredinskem delu profila do porasta nutrientov $\mathrm{v}$ prsti $\mathrm{v}$ recentnih plasteh. Teh okoljskih sprememb se ne da natančno datirati, vendar se jih da povezati $z$ obdobjem večjega človekovega vpliva na Velebitu med 17. in 20. stoletjem in $\mathrm{z}$ ruralno depopulacijo koncem druge polovice 20. stoletja. Ključne besede: kras, vrtače, sredozemske prsti, Velebit, Dinaridi, Hrvaška.

\footnotetext{
${ }^{1}$ ArScAn, UMR 7041-CNRS, 21 allée de l'Université, 92023 Nanterre, France, e-mail: christele.ballut@mae.u-paris10.fr

$2^{*}$ Department of Geography, Faculty of Science, University of Zagreb, Marulićev trg 19/II, 10000 Zagreb, Croatia,

e-mail: sfaivre@geog.pmf.hr
}

Received/Prejeto: 10.3.2011 


\section{INTRODUCTION}

According to its climatic, vegetation, pedologic and ecological properties, Velebit is a typical Mediterranean mountain. It is formed in carbonates which have provided predisposition for the development of rich karstic relief. Owing to the lithological and structural differences, different human impacts, but also due to different climatologic conditions that interchange from colder to warmer periods, the Mediterranean mountains have experienced diverse evolutions (Salomon 2000).

As the soil in karst is sparse it can be found principally in karst depressions like dolines, uvalas and poljes, which represent traps for sediments. The most numerous such forms on Velebit Mt. are the dolines. They are karst landforms that are not only a result of karst dissolution, but also derive from other processes: pedogenetic processes, weathering, collapse, alluvial, aeolian, periglacial processes (Sauro 2003, 2004; Meneghel \& Sauro 2006), and also from glacial processes on Velebit Mt. (Bognar et al. 1991; Bognar \& Faivre 2006). Consequently, in many cases the sediment content at the bottom of the doline more or less masks the rock form.

The study of the Velebit Mt. dolines has started with the analyses of their main morphological properties (Faivre 1992, 1994), where the doline disposition, shape and size were related to the structural properties of the area. Furthermore, we have attempted to establish the connection between spatial distribution of dolines and recent deformations (Faivre \& Bocquet 1999; Faivre \& Reiffsteck 1999a, 1999b, 2002; Faivre 2000; Faivre \& Pahernik 2007). The doline fills (soil) study, which was started in 2002, is a logical continuation of this work.

From prehistoric times, Velebit has been a mountain with a pastoral economy and the dolines (karst de- pressions) have been used for agrarian activity (Faber 1984, 1995a; Faber 2000). Therefore, we have tried in this work to estimate the potential of the sedimentary archives of Velebit Mt., localised in the dolines, seeking to reconstruct a longer socio-environmental history by relating geomorphological, climatic, pedological and environmental conditions.

The studies of soils in the dolines have been conducted by numerous authors (e.g. Lovrenčak 1977; Barany 1980; Magaldi \& Sauro 1982; Bayonnette 1998; Hoyk 1999; Sauro et al. 2009). The question of whether the fills can constitute important records for the reconstruction of climatic-environmental evolution has also been raised recently by Sauro et al. (2009). Their results indicate that the dolines are "filters" for sediments rather than good traps, archiving only some of the climatic and environmental changes.

Detailed analyses of the soil on Velebit Mt. have started long ago. For example, soils from Senjska draga have been studied by Gračanin (1931). Bertović (1975) has presented relations between plant communities and pedosystematic units of soil in the frame of the ecological-vegetational study of the Zavižan area. Systematic investigations of the larger area soil properties were primarily related to the creation of the Main Pedological Map on the scale 1: 50 000, Senj 1 (Vranković 1973) and Senj 3 (Vranković 1974). More recent soil investigations of the Štirovača area have been made by Vrbek \& Pilaš in 2007. Red soils on Velebit Mt. have been also studied by Urushibara $(1976,1981)$ in the broader study frame, while general aspects have been presented by numerous authors (e.g. Rogić 1958; Perica et al. 2002a).

\section{STUDY AREA - GEOMORPHOLOGICAL AND ENVIRONMENTAL PROPERTIES}

Velebit Mountain extends along the Adriatic coast in a NW-SE direction (Fig. 1). It is the longest mountain of the Dinarides mountainous system and of the Republic of Croatia. Velebit Mt. is characterised by anticlinal folding and high degree fracturing. In its different parts they differ in strike, in their inter-relations and in the degree of fracturing. Consequently, three major zones can be distinguished in the structural sense: north Velebit with Senjsko bilo, and central and south Velebit.

Velebit Mt. is mainly constituted of Mesozoic carbonate sequences, from Triassic to Upper Cretaceous, upon which synorogenetic calcareous Jelar breccia can be found, particularly on the littoral side. The whole succession ranges from Middle Permian to Quaternary deposits. The impermeable layers outcrop on central and south Velebit. The significant prevalence of carbonate rocks (limestones and, to a lesser extent, dolomites), which are strongly broken up by tectonic movements, enables the formation of typical karstic relief.

The littoral slope of the Velebit Mt. reveals its bulky character. It is represented by a huge area of rocky karst. Generally, the littoral slope has a particular step-like morphology. After the steep littoral area of about $100 \mathrm{~m}$ high, the first levelled surface appears at 100 to $300 \mathrm{~m}$ 
above sea level. After the steep rise, there is another more or less levelled surface at 700-900 metres a.s.l. This shallow depression is composed of a series of karstic uvalas, some of which have merged together into big ones with large flat bottoms. The genesis of both levelled surfaces is still under debate (Bognar 1992, 2006; Prelogović 1995).

The top parts of Velebit Mt. are characterised by numerous particularly deep karstic forms due to strong tectonic influence, long-lasting karstification as well as to past glacial processes. Well-preserved moraine material has been found at the top parts of the mountain, as well as fluvioglacial sediments on its lower parts (Bognar et al. 1991; Bognar et al. 1997; Bočić et al. 2008; Bočić et al in press). At present, together with the karstic processes, periglacial and nival processes (Perica et al. 2002a) strongly influence relief development.

Velebit is poor with water, but the foot of the NE slope is characterised by frequent springs. Their appearance is the consequence of the complete hydrological barrier of Velebit Mt. The water flows up to the contact with a broken carbonate base, where it sinks and then flows below the surface towards the sea and towards the Zrmanja River (Biondić 1981). The carbonate base, tectonically broken up, results in rivers being rare. The sur- face flows are linked with the poljes that occupy a large area at the foot of the inland Velebit slope.

Numerous factors influence the development of pedological cover. On Velebit Mt. those are climatological, lithological, geomorphological, vegetational and, in more recent times, zoogenic and anthropogenic factors (Perica et al. 2002b). In the upper parts of the mountain, above $900 \mathrm{~m}$, the rendzina and calcomelanosol dominate. Calcocambisol and litosol are often found on the SW slope of the mountain, particularly in its lower parts.

Terra rossa is widespread at low altitude, but rarely continuous (Urushibara 1981). In most cases, terra rossa has polygenetic origin and was formed by mixing of insoluble residue of carbonate rocks with other weathered and eroded sediments (Durn 1996; Durn et al. 1999). The thickness of the terra rossa deposits depends on its position with respect to the relief (Benac \& Durn 1997). At the same time, terra rossa is a paleosoil, a residual soil and a very old and very eroded soil. It can be totally uncarbonated (Nicod 2003b).

As karst processes operate in the atmosphere-soilepikarst system (Barany Kevei 1993, 1995; Pfeffer 1995), the climatological properties are very important. Velebit Mt. represents a barrier that does not allow mixing of the lowest air masses on both

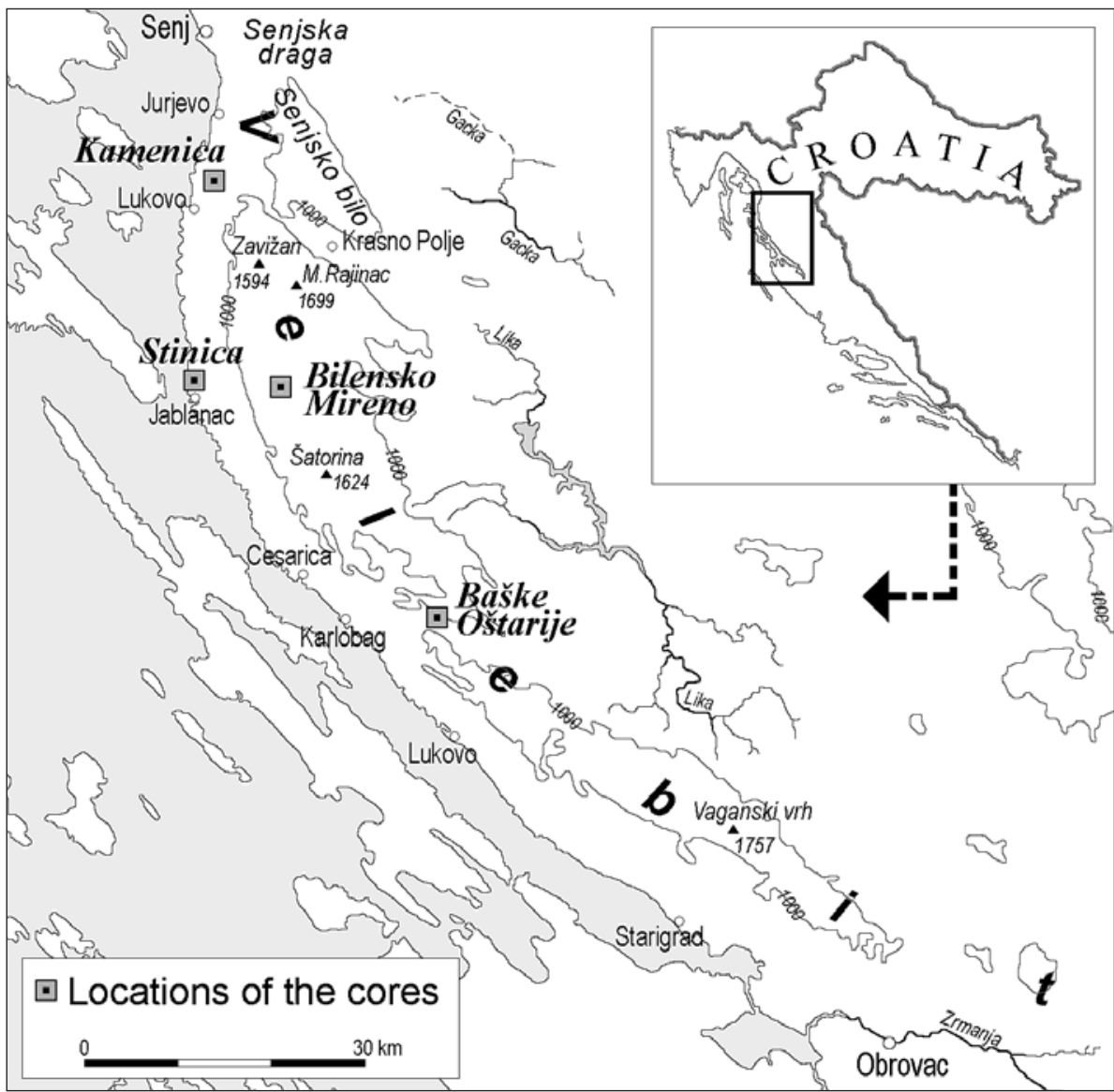

Fig. 1: Study area. slopes up to $1,000 \mathrm{~m}$ altitude. The lowest part of the sea side slope has an average temperature around $15^{\circ} \mathrm{C}$ and the inland area around $8.8^{\circ} \mathrm{C}$. The relief influence becomes distinct in the amount of precipitations. Even if the lowest parts on the sea side receive around $1,100 \mathrm{~mm}$ of precipitations per year, the summer months are dry $(1 / 3$ of yearly precipitation is in the warmer part of the year). The amount of precipitations grows with altitude so that precipitation stands at over 2,000 $\mathrm{mm}$ per year above $900 \mathrm{~m}$, with more uniform distribution (Perica \& Orešić 1997). 
The soil and climatic properties reflect that of the vegetation, which succession is classic for the Mediterranean mountains (Horvat 1949). On the littoral side, forest cover is significantly degraded and is completely degraded to pastures in some areas, what can be partly explained by the economic activities that have occurred in the area (Rogić 1958).

The natural properties of Velebit Mt. did not provide predispositions for considerable settlement. However, archaeological findings point to the existence of numerous prehistorical (Mesolithic to Iron Age) settlements on the littoral Velebit side (Glavičić 1995). The existence of coastal settlements in Roman times is known from the Tabula Peutingeriana, Ptolemai map (Marković 1993; Kozličić 1995) and archaeological findings (Zaninović 1980; Nedved 1995; Fadić 1995; Gluščević 1995). All the Roman settlements were located at the foot of the mountain passes, which allowed communication with the inland.

The absence of cartographic documentation and sources make the geographical reconstruction for this early period very difficult but the relatively slow degradation of the landscape during the $18^{\text {th }}$ century indicates that the littoral slope was most probably already denuded before the $16^{\text {th }}$ century. The number of inhabitants on the Velebit littoral slope during the $14^{\text {th }}$ and $15^{\text {th }}$ centuries cannot be estimated, even roughly. Nevertheless, various documents confirm the small number of sedentary population. The local community lived from agriculture, but cattle breeding were the basis of the economy (Rogic 1958). In the second half of the $15^{\text {th }}$ century, the invasion by the Turks in Lika and north Dalmatia result in almost complete depopulation of the littoral slope. Later, at the end of the $17^{\text {th }}$ century, there were around 2,000-2,500 inhabitants in the northern part and 1,205 in the southern part of the Velebit littoral slope (Rogić 1958).

The continuity of settlement on the Velebit littoral slope can be followed from the end of the $17^{\text {th }}$ century. Some well-conserved Venetian cadastral maps of the area (Disegno delle ville di Starigard di Zara 1709; Rubriche delle ville del Contado Superiore di Zara 1709), published in 1709, show that the landscape was generally similar to the present-day one. Those maps also show that the settlements were located on the first levelled surface and confirm the existence of the summer habitats on the upper levels of the Mountain (Rogic 1958). The basis of the economy was still cattle breeding. In the $18^{\text {th }}$ century, the number of inhabitants increased along with the number of cattle, which generated the problem of exhaustion of pastures that first appeared on the lower part of the Velebit littoral slope. From the beginning of the $18^{\text {th }}$ century till the year 1850 , the number of inhabitants on the southern littoral slope had quadrupled from 1,205 to 4,194 . The number of cattle increased at the same time as well, which directly influenced the degradation of the landscape. At the end of the $18^{\text {th }}$ century, the settlements were finally stabilised, so that the population reached 8,400 inhabitants by the mid- $19^{\text {th }}$ century, which resulted in general poverty and a more intensively degraded landscape.

In 1850 , the population rose to 12,600 inhabitants (Rogić 1958). In the period between 1850 and 1955, the settlements on the Velebit littoral slope were still very small. Most of them (86\%) were located at the contact zone between the first levelled surface with a steep slope, since the littoral zone is not attractive for agricultural and farming communities. This area with local Promina conglomerates and Pleistocene marls (Rogić 1958) allows the existence of ponds, which give water for cattle and provide small depressions suitable for agriculture. The uvalas of the upper levelled surface are much less inhabited, even though there is more arable land at this level - $46 \%$ compared to $39 \%$ at the lower level. $15 \%$ of the arable land can be also found in the high mountainous zone dispersed in the wood clearings of North Velebit.

The majority of the agricultural land-owners from the lower levelled surface - $67 \%$ - had their properties composed of several parcels at the lower levelled surface, a larger arable part at the upper uvalas, and several isolated fields at the upper mountainous level (Rogić 1958). This kind of dispersed land property resulted in periodical settlement. Such vertical control of space allowed acquisition of enough land for survival and production of different crops: cereals at the lower levelled surface, cereals and potatoes on the upper uvalas and potatoes up to $900 \mathrm{~m}$ altitude.

In the first half of the $19^{\text {th }}$ century, the number of inhabitants and cattle greatly increased. As the value of pasture-land was generally very low and as the number of inhabitants became too high for this karstic area so, the degradation of pastures occurred in the second half of the $19^{\text {th }}$ century. From the regular census in the second half of the $19^{\text {th }}$ century, it can be observed that the population constantly grew till the 1910's, followed by regression till 1948 with a small increase in the 19481953 period. Later, in the second half of the $20^{\text {th }}$ century, depopulation followed; the agrarian activity decreased and reforestation began (Rogić 1958).

Beginning in the Neolithic age and recurring regularly, deforestation resulted in the baring of the soil cover, soil erosion by flowing water, its infiltration into the endokarst and baring of rundkarrren. Deforestation principally occurred during the $17^{\text {th }}-19^{\text {th }}$ centuries (Fürst-Bjeliš et al. 2001; Fürst-Bjeliš \& Lozić 2006) while clearing in the mountain areas was carried out later, in 
the $18^{\text {th }}$ and $19^{\text {th }}$ centuries, by burning the land and managing the dolines.

This karstic environment has had a direct influence on the type of settlement and on the particular agrarian structure of the area. During the historical evolution, the topographical surface was modified with the aim to obtain arable land. This was achieved in various ways: by clearing out stones and creating stony piles in parcels, by creating terraces for cultivation, filling up the doline bottoms, or even arranging more open fields in the areas of open karst (Nicod 2003b). The removed stones were often used for the construction of dry walls, which were built for many different purposes: delimitation of transhumance paths, enclosure of wooded areas, as enclosures for domestic animals, for enclosure (protection) of the land parcels, and stone walls terraces and plantation squares (Faber 1984; Nicod 2003a; Aničić \& Perica 2003; Aničić et al. 2004).

Small karstic depressions, mainly dolines, have therefore resulted in various human modifications. One of the basic landscape and cultural elements in the Velebit area are the small dolines bordered with dry stone walls, some of which have been analysed in this paper.

\section{METHODS}

On the $3,000 \mathrm{~km}^{2}$ of the larger Velebit Mt. area, there are around $\sim 40,000$ dolines (Faivre 2000). As the ecological properties differ along the mountain, we have chosen dolines on the littoral slope at between $30-300 \mathrm{~m}$ altitude, and dolines on the top parts of the mountain at between 900 and $1,300 \mathrm{~m}$ altitude. According to the aims of this study, we have also selected dolines which were or still are under anthropogenic influences. From the study of the dolines, many different types of forms can be distinguished resulting from different genetical mechanisms (Sauro 2003). The dolines along the coast (Stinica and Kamenica), are classical corrosional dolines, which appear singly and are rare, while the dolines sampled in the upper parts (Baške Oštarije and Bilensko Mirevo) are located at the bottom of large uvalas and poljes and represent parts of doline fields whose morphogenesis is also related to glacial, periglacial and alluvial processes.

Cores and sediment observations have been carried out in 15 dolines with a soil auger: 1 core at Kamenica, 3 cores at Stinica, 7 cores at Baške Oštarije, 4 cores at Bilensko Mirevo and two doline interspaces (1 at Baške Oštarije and 1 at Bilensko Mirevo). Usually, most of the dolines studied are shallow, but the compaction of the sediment and/or the presence of rocks in depth were a problem for digging through the fill. Consequently, we cannot be sure if the complete stratigraphies of the dolines have been obtained. The soils have been described during the field investigation, specifying: depth, thickness, main macroscopic characteristics of the horizons as well as the vegetation cover. Then, each layer has been sampled to find differences in soil properties related to parent material or environmental evolution (colluvial contributions in particular). Sediment analyses in the laboratory have been made on the more representative and deepest ones: six dolines localised on the top (4 at Baške Oštarije and 2 at Bilensko Mirevo) and two dolines in the lower part near the coast ( 1 at Kamenica and 1 at Stinica) (Fig. 1). As a whole, the sedimentary fills of 8 dolines have been analysed in more detail and 2 doline inter-spaces. Physical and chemical analyses were done (colour, grain size, $\mathrm{pH}, \mathrm{CaCO}_{3}, \mathrm{C}, \mathrm{N}, \mathrm{P}, \mathrm{K}, \mathrm{Mg}$, $\mathrm{CEC}$ ). Colours have been determined on dry soils using standard soil colour charts (Munsell Soils Color Charts 1994). Particles size analyses have been determined with a laser granulometer (LS 350, Beckman Coulter), after organic matter destruction and prior sodium pyrophosphat dispersion of the clay particles. The $\mathrm{pH}$ (water) was obtained according to the French norms (NF) ISO 10390. Calcium carbonates content was determined by hydrochloric acid $(\mathrm{HCl})$ using a calcimeter of Bernard (NF ISO 10693). The proportion of carbon and nitrogen was determined after dry combustion (NF ISO 10694 and ISO 13878). The phosphorus rate was analysed by spectrocolorimetry (Joret \& Hebert 1955), the rates of potassium and magnesium by an extraction with ammonium acetate (Thomas 1982) and the cation exchange capacity (CEC) by the Metson method (Metson 1956). No paleoecological remains and good material for radiocarbon dating have been found. 


\section{RESULTS}

\section{THE DOLINES LOCATED NEAR THE COAST}

There are almost no dolines on the littoral side of the mountain as it is characterised by the lack of vegetation and the lack of water. Nicod (1967) has demonstrated on the karst of Provence that dolines do not develop on rocky karst because there is no soil and no vegetation. On the lower part of the slope, some rare small shallow pen-shaped dolines can be observed, 5-10 m deep, which indicates their feeble vertical development.

Among the rare and isolated dolines, two sites, Kamenica at $280 \mathrm{~m}$ and Stinica $30 \mathrm{~m}$ above sea level, have been selected for this study. Both dolines have been formed on the Palaeogene calcareous breccias, that is, on Jelar deposits (Mamužić et al. 1969).

\section{A) Kamenica}

Kamenica is positioned on the foot slope. It is formed slightly above the lower levelled surface (Fig. 2). Kamenica is $\sim 1.5 \mathrm{~km}$ far from the sea and it is at $280 \mathrm{~m}$ above sea level. It is like a small uvala around $100 \mathrm{~m}$ wide with dolines, in which small settlements with only several houses can be found.

After a few tests, the best core is obtained from the edge of Kamenica (Kamenica 1). It was only $25 \mathrm{~cm}$ long (stopped by rock). The analyses showed a brown clear (7.5YR4/4) clayey soil (clay: $60 \%$, fine loam: $27 \%$ ), with a grumous to polyhedral structure. The soil is decalcified. The $\mathrm{pH}$ is not very high in comparison with other

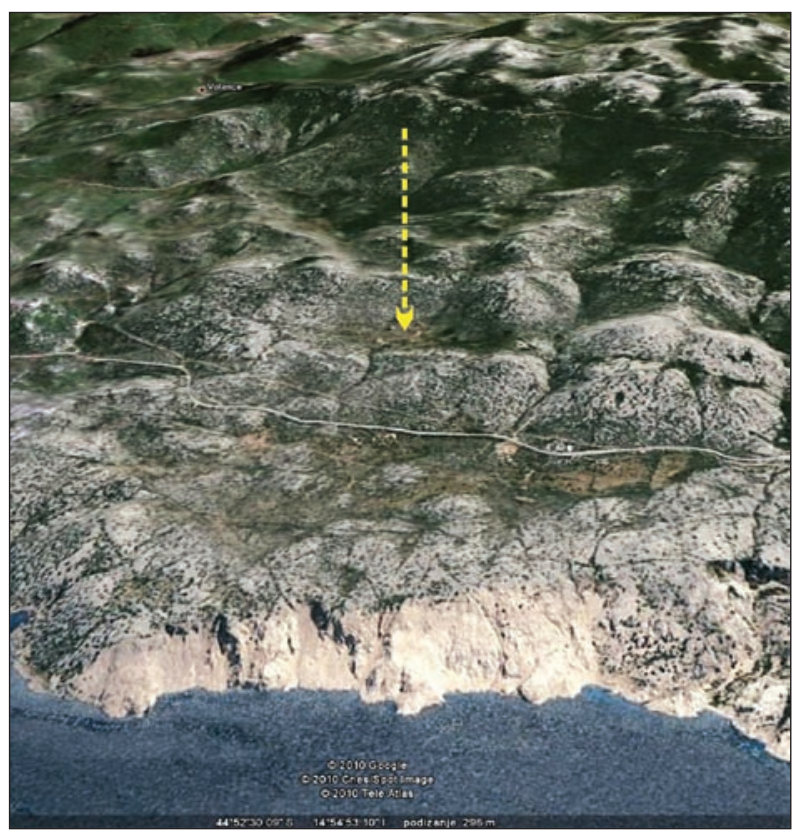

Fig. 2: Kamenica doline (Google Earth). context, but the nutrient elements are well-represented (Tab. 1). The sedimentary sequence is shallow and does not allow efficient observations of environmental dynamics.

\section{B) Stinica}

Stinica is quite large; it is more than $100 \mathrm{~m}$ in diameter and is $70 \mathrm{~m}$ deep. It is located near the sea, less than $100 \mathrm{~m}$ away (Fig. 3). Today, Stinica is characterised by cultivated terraces around the doline. According to its size and position, Stinica has surely had a long-lasting evolution. According to inscriptions from Antiquity the main trail probably started near Stinica close to the seashore, as a several kilometres long boundary wall starts right there and continues on towards the upper Velebit area. Another Roman inscription found near this wall speaks about an agreement, probably referring to grazing boundaries between the Ortoplins (Illyrian tribe from today's Stinica) and the neighbouring Begos tribe (Faber 1984). Thus, this doline was probably used long ago, since cattle-breeding developed together with land cultivation in prehistoric times (Faber 1984, 1995a, 1995b).

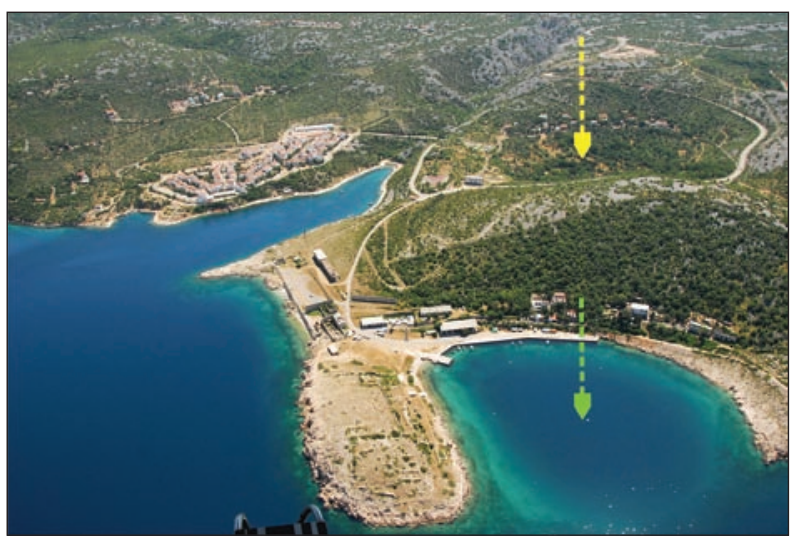

Fig. 3: Stinica doline (yellow arrow) and Bay of M. Stinica (green arrow) - today submerged doline.

One core at the bottom and two cores on the first terrace have been made. Most of the time, the calcareous fragments were too numerous to dig after 20 or $30 \mathrm{~cm}$ of depth. At the bottom, as on the first terrace (Stinica 1), the soil is brown on the surface $(3 \mathrm{~cm}$ of humiferous horizon) and reddish (5YR4/6) at depth (Tab. 1). The sediment has the same characteristics everywhere. It is very clayey $(74 \%)$ with a small proportion of fine loam (17-18\%). It presents the finest texture we observed. It has a polyhedral to grumous structure. The sediment is decalcified. The organic matter and the proportion of nutrients is higher on the surface $(\mathrm{N}, \mathrm{Mg}$ and $\mathrm{K})$ (Tab. 1). 
It contains numerous angular calcareous fragments ( 1 to $2 \mathrm{~cm}$ in diameter on average) that attest to colluvial contribution.

Another similar doline has been observed southwestwards from the Stinica doline, the former being submerged today as a consequence of glacioeustatic changes and tectonic movements during the Holocene (Fig. 3).

sian age are palaeokarstified floatstones and rudstones, with interbeds of dark peloid-ooid packstone-wackestones with stromatolitic laminae (Sokač et al. 1974; Velić et al. 2006). In the area of microtectonically fractured carbonates, which are found between three major faults, numerous dolines and sinks (swallow holes) have been formed. Dolines are also sporadically formed in alluvial sediments of the lowest part of the polje at around $900 \mathrm{~m}$ altitude and are partly filled with periglacial slope deposits.

The central position of this natural pass has had very high importance throughout history (Perica 1998). In the dolines of the Oštarijsko polje, the autochthonous forests have been destroyed by fire in order to obtain ag-

\section{THE DOLINES LOCATED ON THE TOP OF THE MOUNTAIN}

Dolines can appear singly, as was the case on the littoral slope, but they usually appear at the top parts of the mountain as doline fields, where the density highly increases and reaches till 121 dolines per $\mathrm{km}^{2}$. Two major locations have been chosen: the polje of Baške Oštarije and the uvala of Bilensko Mirevo (Figs. 5 \& 6). The Baške Oštarije polje is an area of contact karst developed on the boundary between more and less permeable rocks; accordingly, considered as marginal karst polje (Gams 1978; Perica et al. 2002b). The second location at Bilensko Mirevo is an ancient terminal basin with numerous small dolines.

\section{A) Baške Oštarije}

The Baške Oštarije pass (at 928 m altitude), situated on the main road which crosses Velebit Mt., corresponds to the most narrow part of the mountain. Along the transversal fault of Brušane, the Triasic dolomites are in contact with Permian - Werfenian sediments. The small Baške-Oštarije polje has developed along this contact zone (Perica \& Buzjak 2001). The polje stretches out in an $\mathrm{E}-\mathrm{W}$ direction; it is $3.75 \mathrm{~km}$ long and its width varies from 0.25 to $2.0 \mathrm{~km}$. Together with the Suvaja Valley, it divides the central from the southern part of Velebit Mt. Besides karst and fluvio-karst, the derasion and periglacial processes have been mostly expressed in the relief formation of the area (Perica et al. 2002b).

Clastic-carbonate deposits of the Middle-Upper Triassic (Ladinian-Norian) period crop out in the area of Prpići at Baške Oštarije. The underlying deposits of Ani- ricultural areas during the $18^{\text {th }}$ and $19^{\text {th }}$ centuries. As a consequence of the forest devastation and usually shortlasting rainfalls, strong surface erosion of pedogenetic horizon occurs. Therefore, rocky karst predominates today. Strong outwash is also indicated by continuous occurrence of ash particles in pedohorizons up to $2.2 \mathrm{~m}$ and colluvial soils at swallow holes (Fürst-Bjeliš et al. 2001).

The doline density at Baške Oštarije varies around 15 doline per $\mathrm{km}^{2}$ (source topographical map 1: 25 000). Seven cores have been done at the Baške Oštarije area (Fig. 5). One core has been done between the dolines (BO3) in the relatively lower part of the basin. It shows $40 \mathrm{~cm}$ of a brown (7.5YR4/4) and silty-clay soil. The others have been obtained from the dolines. The most representative ones have been chosen for physical and chemical analyses. Several differences have been observed. The soils can be distributed in two groups: the dolines in relatively upper (BO2 and $\mathrm{BO} 5)$ and in relatively lower position (BO1 and $\mathrm{BO} 7$ ) in the basin.

In the upper position, $\mathrm{BO} 2$ is a little doline $(5 \mathrm{~m}$ in diameter). The core was $40 \mathrm{~cm}$ deep. The sediment is brown (7.5YR4/4), silty-clay (clay: $37-57 \%$ and fine loam: $34-35 \%$ ), with a polyhedral structure. At the surface, the granulometry tends to be finer, and the organic matter and the nutrient contents are higher (CEC, $\mathrm{P}, \mathrm{Mg}, \mathrm{N})$. In depth, the content in $\mathrm{CaCO}_{3}$ increase in feeble proportion. BO5 is somewhat higher in elevation with $7 \mathrm{~m}$ diameter and is enclosed with a dry stone wall. The sediment is still brown (7.5YR4/4), silty-clay (clay: $38-40 \%$ and fine loam: $40-43 \%$ ) with a polyhedral structure. The granulometry is nearly homogeneous along the first $40 \mathrm{~cm}$ of depth. The sediment is 


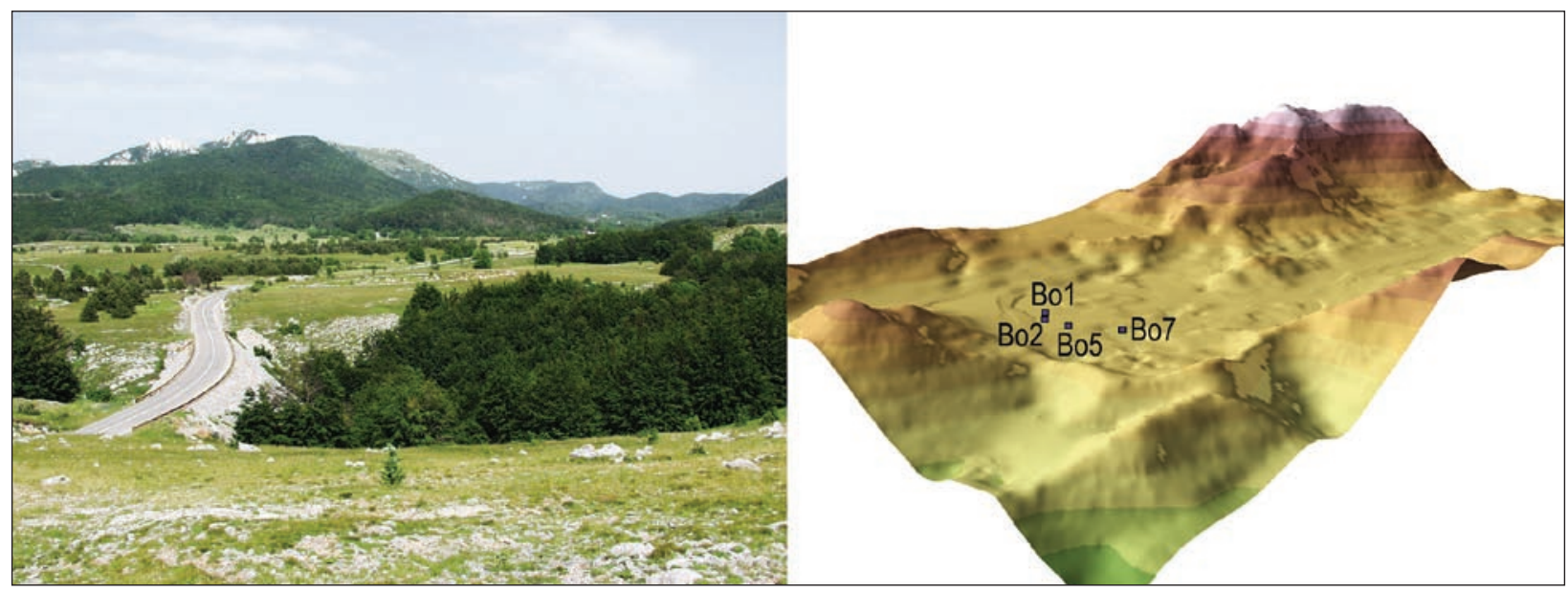

Fig. 5: Polje of Baške Oštarije with sampling locations (Photo: S. Faivre).

decalcified. The proportion of organic matter and soil nutrients is more important at the surface (CEC, $\mathrm{P}, \mathrm{K}$, $\mathrm{Mg}, \mathrm{N}$ ) as in $\mathrm{BO} 2$.

The dolines in relatively lower position present brown to brown-red soils (7.5YR4/4 to 7.5YR4/6 in particular in depth). The sediment is silty clay, always with a small quantity of sand (1.3 to $10,6 \%)$. It has a polyhedral structure. The $\mathrm{pH}$ is high and the $\mathrm{CaCO}_{3}$ contents are higher than in $\mathrm{BO} 2$ and $\mathrm{BO} 5$. The $\mathrm{BO} 1$ $(40 \mathrm{~cm})$ core was made in a rectangular field not really in the lower part of Baške Oštarije, but just lower than $\mathrm{BO} 2$. In $\mathrm{BO} 1$, the sediment is small-sized (clay: $52-59 \%$ and fine loam: 29-34\%) and richer in organic matter and nutrients in depth (CEC, K, Mg, N). The higher proportion of $\mathrm{CaCO}_{3}$ at the surface could attest to colluvial contributions. In the $\mathrm{BO} 7(55 \mathrm{~cm})$ core, the grain size (clay: $48-61 \%$ and fine loam: $27-35 \%$ ) is finer and the nutrient content rises in depth. The finer grain size and the maximal cation exchange capacity - the organic matter, $\mathrm{P}, \mathrm{K}, \mathrm{Mg}, \mathrm{N}$, are in fact higher in the middle of the core (near $45-50 \mathrm{~cm}$ of depth). Up to this horizon, the soil shows impoverishment (as in BO1). We note that we have not sampled the surface of $\mathrm{BO}$, so the vertical evolution of the $\mathrm{CaCO}_{3}$ content cannot be verified.

\section{B) Bilensko Mirevo}

During the Quaternary glacial phases, Velebit Mt. knows a cirque, plateaux and valley glaciers, which leave different types of moraines. Consequently, the glacio-karstic forms are beautifully developed all over the mountain. One particularly interesting site is the uvala of Bilensko Mirevo, which was a former terminal basin where the $4 \mathrm{~km}$ long Alan glacier melted. Relatively thick moraine material indicates several phases of Quaternary pulsations and the progressive retreat of the glacier tangs (Bognar et al. 1991). Such terminal moreinic volumes remodelled karstic heritage by the superpositioning of glacio-karstic and nivo-karstic morphologies as it is also the case e.g. in the Pyrenees (Auly 2007). Consequently, structural predisposition and karstic morphology and the extent of the thick cover of Pleistocene sediments here, together influenced pedogenetic phenomena.

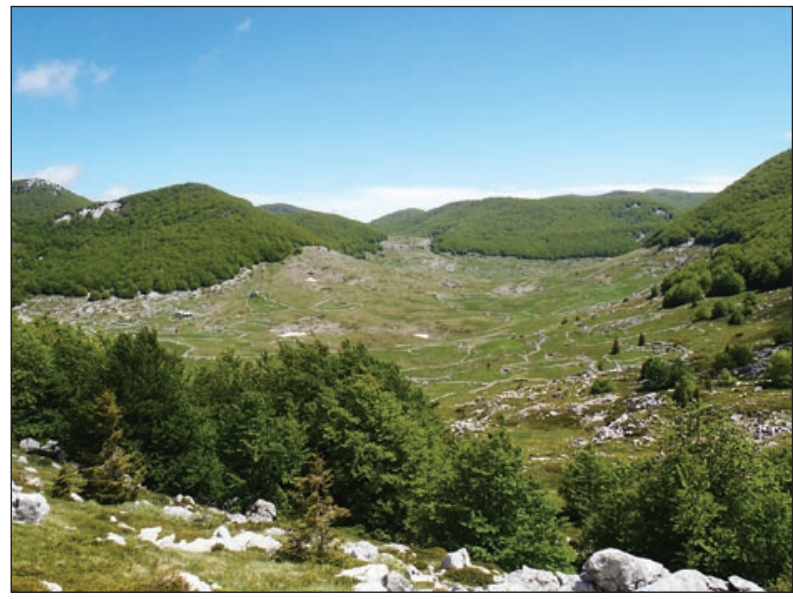

Fig. 6: Dolines in glacial moraine deposits at Bilensko Mirevo (Photo: S. Faivre).

Middle Jurassic carbonate beds, mainly grey to dark grey thick layered and massive mudstones, with occasional scud of late digenetic coarse crystallised greybrown dolomite (Sokač et al. 1974; Velić \& Velić 2009), can be found below the moraine deposits.

Seepage through thick unconsolidated regolith or allogenic detritus over karst rocks generates suffusion depressions. Suffosion causes a dimpling of the surface with a multitude of small dolines at Milensko and 
Tab. 1: Results of physical and chemical soil analyses.

\begin{tabular}{|c|c|c|c|c|c|c|c|c|c|c|c|c|c|c|c|c|c|c|c|c|}
\hline క & $\stackrel{\bar{m}}{=}$ & $\stackrel{\stackrel{\sim}{g}}{=}$ & $\stackrel{\infty}{\circ}$ & 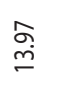 & $\begin{array}{l}\stackrel{ \pm}{\infty} \\
\stackrel{0}{0}\end{array}$ & $\begin{array}{l}\stackrel{0}{\circ} \\
\stackrel{0}{0}\end{array}$ & $\begin{array}{l}\hat{b} \\
=\end{array}$ & 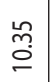 & $\stackrel{n}{\circ}$ & ᄋ̊ & $\stackrel{\Xi}{\stackrel{\Xi}{\rightleftharpoons}}$ & 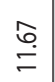 & ळ̊ & $\stackrel{\infty}{m}$ & $\hat{\sigma}$ & $\begin{array}{l}\infty \\
\underset{\sigma}{\infty}\end{array}$ & $\underset{\sigma}{\mathscr{\sigma}}$ & $\stackrel{\text { }}{=}$ & $\begin{array}{l}\text { పे. } \\
\text { ○े }\end{array}$ & \\
\hline$z$ & $\stackrel{\sim}{m}$ & $\stackrel{\leftrightarrow}{\stackrel{\circ}{~}}$ & $\stackrel{\leftrightarrow}{\sim}$ & $\stackrel{\stackrel{\circ}{N}}{\text {. }}$ & 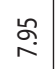 & $\bar{\sigma}$ & $\underset{\sim}{\stackrel{\sim}{\sim}}$ & $\underset{\stackrel{\leftrightarrow}{\infty}}{\stackrel{\leftrightarrow}{+}}$ & $\stackrel{\sim}{\sim}$ & $\bar{i}$ & $\stackrel{\infty}{\sim}$ & $\stackrel{\leftrightarrow}{\infty}$ & $\frac{a}{m}$ & $\stackrel{\leftrightarrow}{\circ}$ & $\stackrel{\infty}{\stackrel{\sim}{\longrightarrow}}$ & $\underset{f}{\stackrel{m}{f}}$ & $\begin{array}{l}\mathscr{\infty} \\
\stackrel{+}{+}\end{array}$ & 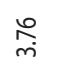 & $\stackrel{\leftrightarrow}{\circ}$ & \\
\hline 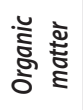 & $\bar{o}$ & $\stackrel{m}{i n}$ & $\stackrel{\infty}{\stackrel{\infty}{n}}$ & $\frac{n}{6}$ & 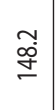 & $\underset{\Xi}{\cong}$ & $\stackrel{\dot{q}}{\dot{\gamma}}$ & $\begin{array}{l}m \\
\stackrel{\infty}{0}\end{array}$ & $\stackrel{m}{n}$ & ‡্. & $\begin{array}{l}\text { ஜீ } \\
\dot{q}\end{array}$ & $\overline{\vec{m}}$ & 趈 & $\begin{array}{l}\infty \\
\stackrel{\infty}{0} \\
0\end{array}$ & $\stackrel{n}{\sim}$ & 尺̊ & 8 & $\bar{\varnothing}$ & $\frac{\stackrel{g}{m}}{m}$ & \\
\hline$\checkmark$ & $\begin{array}{l}\text { ồ } \\
\text { ồ }\end{array}$ & ๙্心 & 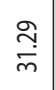 & $\begin{array}{l}\stackrel{\circ}{\circ} \\
\text { w }\end{array}$ & $\underset{\infty}{\stackrel{\nabla}{\circ}}$ & 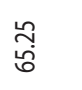 & 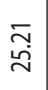 & $\stackrel{\infty}{\circ}$ & $\underset{\mathscr{\gamma}}{\stackrel{\mathscr{q}}{ }}$ & ঐે & 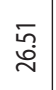 & 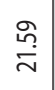 & $\stackrel{\substack{n \\
m}}{m}$ & $\stackrel{\circ}{\circ}$ & 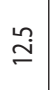 & 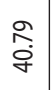 & 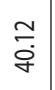 & గñ & 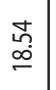 & \\
\hline 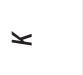 & $\overline{\tilde{o}}$ & ત્ర & $\stackrel{\stackrel{\sim}{O}}{0}$ & $\overline{\tilde{o}}$ & $\stackrel{\sim}{\sim}$ & $\stackrel{\check{0}}{0}$ & $\frac{9}{0}$ & $\hat{m}$ & $\stackrel{\circ}{\circ}$ & $\frac{9}{0}$ & F & 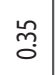 & $\cong$ & $\frac{n}{\circ}$ & $\stackrel{n}{\circ}$ & $\stackrel{n}{\circ}$ & $\stackrel{\Delta}{0}$ & 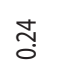 & $\stackrel{\circ}{\circ}$ & \\
\hline$\stackrel{D}{\Sigma}$ & $\widetilde{\widetilde{o}}$ & స్ర & $\frac{9}{0}$ & 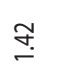 & $\stackrel{\sim}{\sim}$ & $\stackrel{\infty}{i}$ & $\underset{\delta}{\widetilde{\delta}}$ & $\frac{9}{0}$ & $\overline{0}$ & চু & $\underset{\sim}{\stackrel{\circ}{i}}$ & 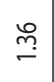 & $\frac{\infty}{\circ}$ & 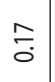 & $\stackrel{\frac{n}{0}}{\frac{0}{0}}$ & $\stackrel{\sim}{\stackrel{\circ}{0}}$ & $\frac{\infty}{0}$ & $\stackrel{\circ}{\circ}$ & $\stackrel{\circ}{\circ}$ & \\
\hline$a$ & $\stackrel{n}{\circ}$ & $\stackrel{\infty}{\circ}$ & $\stackrel{\infty}{\circ}$ & 응. & $\stackrel{+}{\circ}$ & $\stackrel{\circ}{\circ}$ & $\stackrel{0}{0}$ & $\stackrel{0}{\circ}$ & $\stackrel{n}{\circ}$ & ठั & $\stackrel{\sim}{\circ}$ & $\stackrel{\circ}{\circ}$ & $\stackrel{\infty}{\circ}$ & 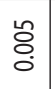 & oे & $\widehat{\widehat{\sigma}}$ & $\begin{array}{l}\stackrel{\Delta}{\Delta} \\
\stackrel{0}{0}\end{array}$ & $\overline{\tilde{o}}$ & $\begin{array}{l}\tilde{O} \\
0 \\
0\end{array}$ & \\
\hline 岕 & $\grave{i}$ & $\stackrel{\stackrel{\infty}{\sim}}{\sim}$ & 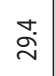 & $\stackrel{\stackrel{\sim}{\sim}}{\text {. }}$ & $\bar{g}$ & 雍 & $\underset{\infty}{\infty}$ & 岕 & 岂 & $\stackrel{\stackrel{\sim}{\sim}}{\sim}$ & 岕 & $\stackrel{\sim}{\sim}$ & $\overline{\grave{\sim}}$ & $\bar{g}$ & $\stackrel{\widehat{n}}{\underline{n}}$ & $\underset{\sim}{\sim}$ & $\stackrel{m}{\sim}$ & 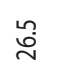 & 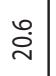 & \\
\hline $\mathbb{\Xi}^{m}$ & - & $\sim$ & - & 으 & 으 & 으 & in & $\sim$ & $\sim$ & $\mathscr{F}$ & ৪ & $\stackrel{\dddot{\vartheta}}{\simeq}$ & $\sim$ & $\sim$ & - & - & - & $\stackrel{\infty}{\infty}$ & $\bar{\sim}$ & \\
\hline I & ñ & $\stackrel{n}{N}$ & $\stackrel{ \pm}{N}$ & $\infty$ & $\stackrel{\circ}{\sim}$ & $\approx$ & $\infty$ & $\stackrel{\infty}{0}$ & $\bar{\pi}$ & $\stackrel{g}{\curvearrowright}$ & $\infty$ & $\bar{\infty}$ & $\stackrel{m}{\sim}$ & $\stackrel{\circ}{\stackrel{2}{*}}$ & $\stackrel{\circ}{\sim}$ & in & $\hat{n}$ & $\stackrel{r}{r}$ & $\infty$ & \\
\hline 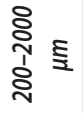 & $\approx$ & $a$ & 0 & $\simeq$ & 0 & $r$ & on & $\sigma$ & 0 & q & - & 0 & in & - & - & - & - & $\approx$ & $g$ & \\
\hline 蓇 & ㄱ & $\stackrel{2}{\sim}$ & $\bar{\sim}$ & 8 & $\stackrel{n}{n}$ & $\bullet$ & $\approx$ & ㄱ & $=$ & 8 & $\simeq$ & $\approx$ & 요 & $\circ$ & $\approx$ & $\sim$ & $\sigma$ & $\bar{\pi}$ & 8 & \\
\hline 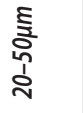 & б & 8 & 苚 & 능 & $\bar{n}$ & 능 & $\bar{m}$ & $\hat{6}$ & $\stackrel{ \pm}{=}$ & 于 & 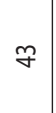 & $\widetilde{\sigma}$ & $\underset{\sigma}{ }$ & $\stackrel{\sim}{\sim}$ & $\stackrel{\circ}{\grave{\sim}}$ & $\bullet$ & ৪ & 능 & $\Xi$ & \\
\hline 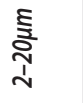 & $\underset{\sim}{\stackrel{\sim}{\sim}}$ & $\stackrel{2}{2}$ & $\stackrel{\Im}{\Omega}$ & ్ㅗ & $\stackrel{\infty}{m}$ & $\stackrel{\mathcal{F}}{\mathrm{m}}$ & $\stackrel{m}{n}$ & శे & \& & $\stackrel{n}{\curvearrowright}$ & $\stackrel{\infty}{m}$ & 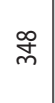 & $\stackrel{\infty}{\sigma}$ & $\stackrel{\infty}{\mathscr{f}}$ & $\ddot{\mathscr{q}}$ & $\bar{\sigma}$ & $\stackrel{\infty}{\mathscr{\gamma}}$ & $\stackrel{\infty}{\sim}$ & $\underset{\sim}{\stackrel{\sim}{\sim}}$ & \\
\hline 疍 & 용 & $\stackrel{\circ}{\sim}$ & 옴 & $\widetilde{\sim}$ & 呙 & in & 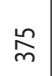 & $\stackrel{\circ}{\infty}$ & 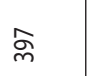 & $\stackrel{\infty}{\mathscr{f}}$ & $\stackrel{8}{\circ}$ & 只 & $\stackrel{m}{\text { m }}$ & $\bar{m}$ & $\stackrel{\sim}{m}$ & $\stackrel{\circ}{f}$ & $\bar{g}$ & $\frac{a}{i n}$ & 号 & \\
\hline बूँ & 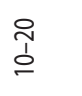 & ণ্ণি & 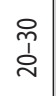 & 客 & $\begin{array}{l}\text { P্ } \\
\text { d }\end{array}$ & 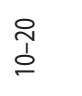 & $\begin{array}{l}\text { 아 } \\
\text { ’े }\end{array}$ & $\begin{array}{l}\stackrel{T}{1} \\
\vdots \\
0\end{array}$ & 암 & 吕 & 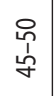 & $\begin{array}{l}\tilde{h} \\
0 \\
0\end{array}$ & 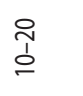 & $\begin{array}{l}\text { ơ } \\
\text { dे } \\
\text { na }\end{array}$ & 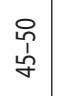 & $\begin{array}{l}\text { 员 } \\
0 \\
\text { in }\end{array}$ & $\begin{array}{l}\text { P } \\
\grave{b}\end{array}$ & 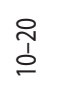 & 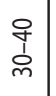 & 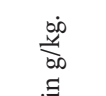 \\
\hline 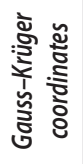 & 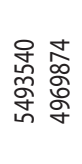 & 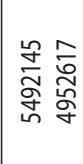 & & 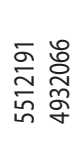 & & 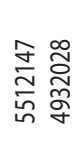 & & & 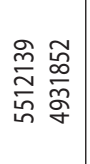 & 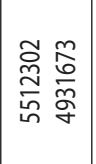 & & & 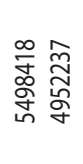 & & & & & 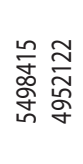 & & $\begin{array}{l}\Delta \\
u \\
z \\
u \\
0 \\
0\end{array}$ \\
\hline 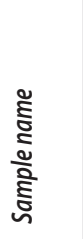 & 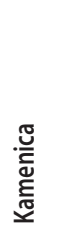 & & 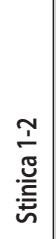 & 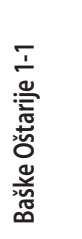 & 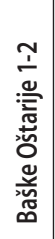 & 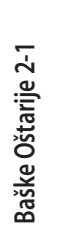 & 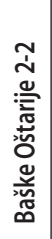 & 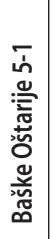 & 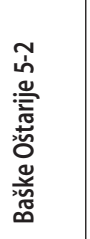 & 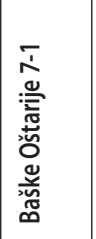 & 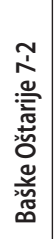 & 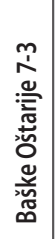 & 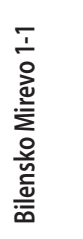 & 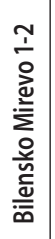 & 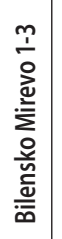 & 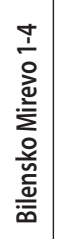 & 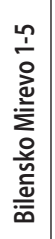 & 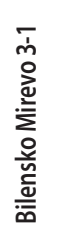 & 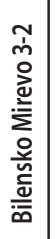 & 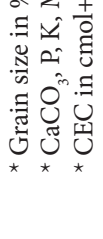 \\
\hline
\end{tabular}


Dundović Mirevo (Fig. 6) as glacial till has been deposited into a well-developed karst floor, which sporadically outcrops in the upper parts of the uvalas.

The uvala of Bilensko Mirevo, situated at 1,350 m altitude, was intensively cultivated in the $19^{\text {th }}$ century by seasonal inhabitants from the coast, who produced there almost all the needed food on the mountain during their stay. According to Faber (1984), the traces of small parcels from ancient times can be observed on the aerial pictures, testifying to the early anthropogenic impact on the area.

At Bilensko Mirevo, the doline density is around 11 dolines per $\mathrm{km}^{2}$ (source topographical map 1: 25000 ). The Bilensko Mirevo is a rather large uvala around 1.5 $\mathrm{km}$ long and $1 \mathrm{~km}$ wide. At Bilensko Mirevo, two suffosional dolines (BM1, BM3), and an inter-doline space (BM4) have been cored and sampled.

On the doline inter-space (BM4), the substratum has not outcropped. The space is used for agriculture and is included in a rectangular plot outlined by a dry stone wall. The soil is $20 \mathrm{~cm}$ deep (stopped by rock) (brown $(7.5 \mathrm{YR} 4 / 4)$, clayey and silty, with a polyhedral structure.

Physical and chemical analyses have been carried out at BM1 and BM3. BM1 is one of the biggest dolines of Bilensko Mirevo (25-30 $\mathrm{m}$ in diameter) and it is surrounded with a dry stone wall. The core obtained from $\mathrm{BM} 1$ is the longest one (stopped by rock; $70 \mathrm{~cm}$ deep). The sediment is brown $(7.5 \mathrm{YR} 4 / 4)$, silty clay loam (clay: $30-49 \%$, fine loam, $42-48 \%$, coarse silt $6-22 \%$ ), with a polyhedral structure. Some calcareous fragments are characteristic all along the profile. $\mathrm{CaCO}_{3}$ is nearly absent. Below $50 \mathrm{~cm}$, the organic matter and the soil nutrients are higher (CEC, $\mathrm{C}, \mathrm{N}, \mathrm{P}, \mathrm{K}, \mathrm{Mg}$ ), the grain size is finer, but the $\mathrm{pH}$ is lower $(50-55 \mathrm{~cm})$ (Tab. 1). We no- ticed that the surface $(10-20 \mathrm{~cm})$ became clayey and was also rich in nutrients. Between 50 and $20 \mathrm{~cm}$ of depth, the nutrients contents decrease. Two micro-charcoals have been observed near $15 \mathrm{~cm}$ and $48 \mathrm{~cm}$ of depth. They look like very small needles (less than $2 \mathrm{~mm}$ ). They were probably brought about by colluviation and consequently have not been used for radiocarbon dating.

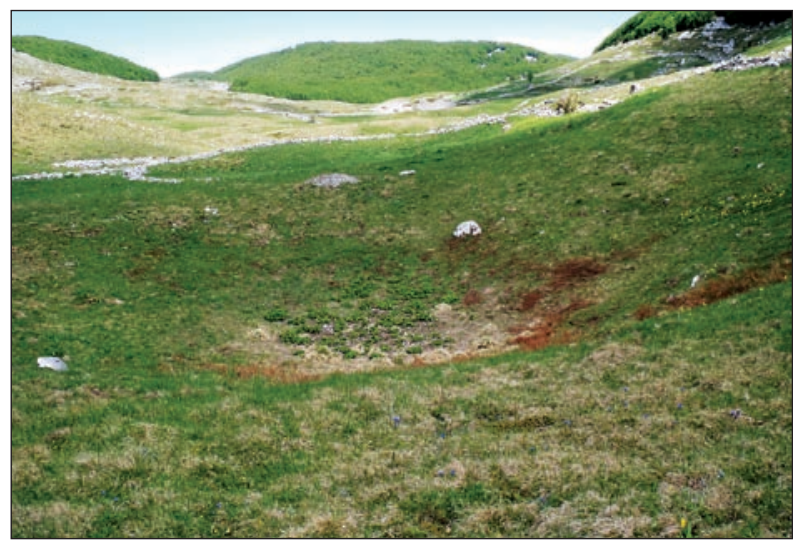

Fig. 7: Doline MB3 at the Milensko Mirevo (Photo: S. Faivre).

The BM3 doline is $6 \mathrm{~m}$ deep and $27 \mathrm{~m}$ in diameter (Fig. 7). The core was stopped at $40 \mathrm{~cm}$ by rock. The results of physical and chemical analyses differed from BM1. The sediment is more clayey (clay: $51 \%$, fine loam, $28 \%$ ). It also contains more sand, especially at depth. The sediment is not decalcified and shows an increase of $\mathrm{CaCO}_{3}$ content on the surface. Over the $40 \mathrm{~cm}$ observed, the grain size was finer, the organic matter and the nutrient content were more important near the top of the soil (CEC, $\mathrm{P}, \mathrm{K}, \mathrm{Mg}$ ), but the observed rates were higher than in BM1.

\section{DISCUSSION}

\section{THE CLOSE CORRELATION BETWEEN GEOLO- GICAL/GEOMORPHOLOGICAL STRUCTURE AND LAND OCCUPATION}

Exposed geomorphological, geologic and geoecological properties, mutually interconnected, determine in a particular way the evolution of land occupation. As has been explained, dolines and uvalas have been particularly important location factors on Velebit Mt. from ancient times, that is, the spatial distribution of dolines directly influenced spatial distribution of settlements. The second important factor influencing settlement location is fresh water sources, defined by local geological proper- ties, which can be found right along the first levelled surface $(100-300 \mathrm{~m})$ where the primary settlements are. But dry summer months, lack of water, thin soils in a small number of dolines, modest pastures and, therefore, scarcity of food, compel people to make use of the natural (geomorphologic) properties of the mountain, that is, to start the vertical control of the space. So people from the coast searched for additional land and found it on the next structural line (the second levelled surface at 700-900 m altitude), where uvalas are aligned. During summer, the same people occupied high mountain uvalas (which represent the third altitudinal level at around 1,300 m) with 
a great number of dolines due to the "accelerated corrosion" in central parts of the depressions and of structural blocks (Gams 2000; Faivre \& Pahernik - 2007). These numerous dolines were particularly appropriate for agriculture and cattle breeding. The adaptation and exploitation of those natural properties of the area provided the predisposition for survival in the environment where living was always hard and where, according to a Croatian saying, "stones grow in the fields".

Velebit Mt. presents the types of land-use typical to Mediterranean countries that produce changes in the surface, e.g. deforestation and adaptation of karst surfaces for agriculture (Nicod 2003a; Gams 1991). Therefore, the doline also becomes an anthropogenic karstic form, because those anthropogenic impacts can be found in their soils such as are found in the case of Bilensko Mirevo and Baške Oštarije. The increased solution in the epikarst zone (Pahernik 1998; White 1988; Gams 2000; Ford \& Williams 2007), together with appropriate climatologic properties in the upper parts of the Mountain, largely contribute to the accelerated corrosion that is also reflected in the length of the doline soil profiles of the area.

\section{THE SEDIMENTARY ARCHIVES SIGNIFICANCE}

Due to the bad conditions for coring and the absence of datable material, most of the results incline to be rather indicative. Nevertheless, answers to several questions have been documented. The most important one is the thickness of soil in the dolines and sometimes also in the doline interspace. Water content is more important when the soil is deep. Moreover, there is a domination of loamy clay texture classes, a high $\mathrm{pH}$ and good organic matter and nutrient content. So the dolines surely correspond to the best agricultural areas on this rocky mountain (the rock appear in surface outside the dolines). But many differences between the studied areas, and even between nearby dolines from the same doline field have been observed.

Furthermore, on the littoral side, the soils have a finer grain size and are decalcified, while the $\mathrm{CaCO}_{3}$ content increases in several dolines on the upper part of Velebit Mountain. The soils are brown everywhere, except in Stinica. They are reddish (terra rossa) in this doline located just beside the sea.
The observations made in the same doline fields at Baške Oštarije and Bilensko Mirevo are particularly interesting; we noticed differences from one doline to another. The main differences concern the grain size, the $\mathrm{CaCO}_{3}$ content, the organic matter and the nutrient content. The analyses show that the best nutrient contents are associated to the finer granulometry, sometimes in depth (BO1, BO7, BM1) and sometimes on the surface (BO2, BM1, BM3). Occasionally, the differences between the depth and the surface are not significant (Stinical, BO5). These differences can be partly explained by the exposure of the doline and by changes in vegetation cover (Barany 1993; Aniko 1999). However, the differences concerning the grain size and the $\mathrm{CaCO}_{3}$ content seem to depend on their position in the basin at Baške Oštarije, since the dolines located in the relatively lower parts have a finer granulometry and are not decalcified. At Bilensko Mirevo, differences between the dolines can also depend on the type of doline and their morphology. The BM3 doline is in both a lower position in the basin and morphologically deeper than BM1. The higher proportion of $\mathrm{CaCO}_{3}$ attests to colluvial contributions (BO1, BO7, BM3). In other dolines, like BM1 and Stinica, the colluvial contributions are also attested to, but only by the presence of more or less rounded calcareous fragments.

Nevertheless, most of the cores are not long and there is no clear stage in the sedimentary sequences. The processes are homogeneous. This homogeneity has been also observed elsewhere. For example, the samples of the doline fill on the Gaverghera plateau (Venetian pre-Alps, Italy) show a very homogeneous overall trend in their cumulative particle size curves and in the percentage content of sand, silt and clay (Sauro et al. 2009). Only the more complete bore profiles, $\mathrm{BO} 7$ and especially BM1, allow proposing a hypothesis for future research. They have shown an impoverishment in the more recent part of the soil that could perhaps correspond to a period of intense land use between the $17^{\text {th }}$ and $19^{\text {th }}$ century. This evolution becomes inverse in the surface horizon (only observed in BM1), perhaps because of the rural depopulation observed since the last century. Unfortunately, the rare micro-charcoals observed have not allowed the datation of the observed processes. 


\section{CONCLUSION}

The study on dolines and soils reveals the close links existing between local lithological and structural situations, neotectonic activity, and geomorphic and pedogenetic processes. However, their evolution is also sensitive to climatic and environmental changes, as well as to land use impacts. So, the current aspect of the Velebit Mt. dolines is the result of phases of intense karstic morphogenesis, accompanied by obvious pedogenetic processes, the velocity of which was related to climatic conditions but also to human impacts.

The relatively large but shallow dolines at the littoral side of Velebit Mt., which appear singularly, are older forms. At the Stinica doline, below the thin horizon of brown soil, terra rossa formation has been found. On the other hand, the dolines situated on the karst polje and karstic uvalas up to $900 \mathrm{~m}$ altitude are characterised by small and relatively young dolines, most probably formed after LGM. They form doline fields in moraine material so their morphogenesis is associated with glacial at Bilensko Mirevo and periglacial origin (morphogenetic processes) at Baške Oštarije.

In this study we have also found that the soil depth in the dolines is differently distributed. They are mainly shallow in the littoral zone, up to $30 \mathrm{~cm}$, while in the up- per part the dolines have deeper soils up to $70 \mathrm{~cm}$. Consequently, the ecological conditions seem much more appropriate for soil formation in those upper zones. The relatively thin soil cover in the Stinica area may also be related to its open-sided morphology. It is opened toward the Velika Draga gully and this may be related to the erosion periods in the past.

These analyses reveal that the soils in the dolines were the best for agricultural activities in the past, as well as also being so today. So, the found impoverishment of the soil horizon could be correlated with the increased environmental impact in the period between the $17^{\text {th }}$ and first half of the $20^{\text {th }}$ century (dated by: Rogić 1958; Fürst-Bjeliš et al. 2001; Nicod 2003a; Fürst-Bjeliš \& Lozić - 2006), as a consequence of the increasing population density and increased land use.

To conclude, the studied dolines of Velebit Mt. do not present very good data for environmental history reconstruction for two reasons. The first reason is the lack of datable material and the second the important differences observed between nearby dolines in the same area, linked to the topography or to their genesis, which constitute another difficulty to assure the representatives of the sedimentary archives.

\section{ACKNOWLEDGEMENT}

This research was supported by the Ministry of Science, Education and Sport of Republic of Croatia (Project 1191191306-1305 Geomorphological and geoecological research of Karst areas in Croatia) and by GEOLAB, UMR
6042-CNRS, France, which is warmly acknowledged. We remain indebted to Ivica Rendulić and Mladen Pahernik for the drawing of the figures.

\section{REFERENCES}

Aničić, B. \& D. Perica, 2003: Structural features of cultural landscape in the karst area (landscape in transition).- Acta Carsologica, 32, 1, 173-188.

Aničić, B., Reichner.- \& D. Perica, 2004: Structural vocabulary of cultural landscape on the island of Krk (Croatia).- Acta Carsologica, 33, 1, 101-115.

Aniko, Z., 1999: Research on the soils of karst areas in Hungary (example from Bükk Mountain).- Acta Carsologica, 28, 2, 203-210.
Auly, T., 2007: Quelques morphologies de rapport karst/ glaciare dans les Pyrénées (France).- In: Tyc, A. \& K. Stefaniak (eds.) Karst and Cryokars, $8^{\text {th }}$ Proceedings of GLACKIPR Symposium, $19^{\text {th }}-26^{\text {th }}$ March 2007, Poland. Studies of the Faculty of Earth Sciences, University of Silesia, 129-154, Sosnowiec Wrocłav.

Barany, I., 1980: Some data about the physical and chemical properties of the soil of karst dolines.- Acta Geographica, 37-49. 
Bárány-Kevei, I., 1993: A study of the Karst-Ecological system of karst.- Acta Geogr. Szegediensis, 34, (Spec. Issue), 155-162.

Bárány-Kevei, I., 1995: Factors of the environmental system of karst.- Acta Geogr Univ. Szegediensis, 34, (Special issue. Hommage to Jakucs L.), 155-161.

Bayonnette, V., 1998: La dépression de Soulages (Caussee de Sauveterre, Lozère).- Sud-Ouest Européen, 3, 13-28.

Benac, Č. \& G. Durn, 1997: Terra rossa in the Kvarner area - geomorphological condition of formation.Acta Geographica Croatica, 32, 7-19.

Bertović, S., 1975: Ekološko-vegetacijske značajke okoliša Zavižana u sjevernom Velebitu (Ecological-vegetation properties of the Zavižan environment in the Northern Velebit).- Glas.šum. pokuse, 18, 5-75.

Biondić, B., 1981: Hidrogeologija južnog dijela Hrvatskog primorja $i$ Like (Hydrogeology of the southern part of the Croatian Littoral and Lika).- PhD thesis. University of Zagreb, Faculty of Science, pp. 214.

Bočić, N., Faivre, S. \& M. Kovačić, 2008: Underground karst features and glacail sediments - Example from "Snježnica u Štirovači" cave on the Velebit Mt. (Croatia).- In: Zupan Hajna, N. \& A. Mihevc (eds.) $16^{\text {th }}$ International karstological school "Classical karst", Karst sediments - Guide book \& Abstracts, $16^{\text {th }}-21^{\text {th }}$ June 2008, Postojna. Karst research institute ZRC SAZU, 62, Postojna.

Bočić, N., Faivre., S., Kovačić, M. \& N., Horvatinčić, 2012: Cave development under the influence of Pleistocene glaciation in the Dinarides - an example from Štirovača Ice Cave (Velebit Mt., Croatia), Z. Geomorph. N.F., in press.

Bognar, A., 1992: Pedimenti Južnog Velebita (Pediments of the South Velebit Mountain Range).- Geografski glasnik, 54, 19-32.

Bognar A., 1994: Neke od temeljnih značajki razvoja pedimenata u gorskoj zoni Vanjskih Dinarida (Some Basical Characteristics of the Evolution of the Pediments in the Mountain Zone of the Outer Dinarides).- Geografski glasnik, 55, 21-31.

Bognar, A., 2006: The Geomorphological Evolution of Dinarides.- In: Menichetti, M. \& D. Mencucci, (eds.) Adria 2006 International Geological Congress on the Adriatic area: field trip guide, $19^{\text {th }}-20^{\text {th }}$ June 2006, Urbino. Instituito di Science della Terra, Universita di Urbino, 23-26, Urbino, Italy.

Bognar, A., Faivre, S. \& J. Pavelić, 1991: Tragovi oledbe na Sjevernom Velebitu (Glaciation Traces on the Northern Velebit).- Geografski glasnik, 53, 27-39.
Bognar, A., Faivre, S. \& J. Pavelić, 1997: Tragovi oledbe na Srednjem Velebitu (Glaciation Traces on the Central Velebit).- Senjski zbornik, 25, 1-16.

Bognar, A. \& S. Faivre, 2006: Geomorphological Traces of the Younger Pleistocene Glaciation in the Central Part of the Velebit Mt.- Hrvatski geografski glasnik, $68,2,19-30$.

Božičević, S., 1987: Prikaz intenziteta i dubine okršavanja na primjerima speleoloških pojava u Južnom Velebitu (Survey of the intensity and depth of karstification based on the speleo-features in the Southern Velebit Mt.).- In: Bognar, A., (Ed.) Zbornik radova II znanstvenog skupa geomorfologa, Gospić Južni Velebit, $18^{\text {th }}-25^{\text {th }}$ June 198, Gospić. PMF, Geografski odjel, 113-124, Zagreb.

Disegno delle ville di Starigard e tribani di Castel Vinier, poste nella Morlacca, confinante con l'impero, 1709. Cadastral maps $n^{\circ}$. 238-242, Zadar State Archives.

Durn, G., 1996: Origin, composition and genesis of terra rossa in Istria.- $\mathrm{PhD}$ thesis (in Croatian). University of Zagreb, pp. 204.

Durn, G., Ottner, F. \& D. Slovenec, 1999: Mineralogical and geochemical indicators of the polygenetic nature of terra rossa in Istria, Croatia.- Geoderma, 91, $125-150$.

Faber, A., 1984: Tragovi poljoprivrednih djelatnosti u perthistorijsko i antičko doba na zračnim snimkama tla Hrvatske (Traces of the agricultural activities in the prehistoric and ancient times on the areal photos).- Bilten Savjeta za daljinska istraživanja i fotodokumentaciju, JAZU, 5, 24-37.

Faber, A., 1995a: Ekonomsko značenje putova oko Paklenice u prapovijesti, antici i srednjem vijeku (Economic significance of passages around Paklenica national park in the prehistoric, ancient and medieval times).- In: Tvrtković, N. (ed.) Paklenički zbornik, Vol.1, Simpozij povodom 45.godišnjice NP Paklenica, $19^{\text {th }}-22^{\text {th }}$ October 1994, Starigard-Paklenica. Naša djeca offset tisak, 255-260, Zagreb.

Faber, A., 1995b: Život velebitskog stočara i njegov odnos prema smrti (The life of the Velebit cattle-breeder and his relation to the death).- Senjski zbornik, 22, 157-170.

Faber, A., 2000: Život na Velebitu u pretpovijesno doba (The life on Velebit plateau in the prehistory time).Senjski zbornik, 27, 15-44.

Fadić, I., 1995: Starigard u Antici (Starigrad in antiquity).- In: Tvrtković, N. (ed.) Paklenički zbornik, Vol.1, Simpozij povodom 45.godišnjice NP Paklenica, $19^{\text {th }}-22^{\text {th }}$ October 1994, Starigard-Paklenica. NP Paklenica, 229-236, Zagreb. 
Faivre, S., 1992: The analysis of the dolines density on the North Velebit and Senjsko bilo.- In: Bognar, A. (ed.) Proceedings of international symposium "Geomorphology and sea" and meeting of the Geomorphological commission of the Carpatho-Balkan countries, $22^{\text {th }}-26^{\text {th }}$ September 1992, Mali Lošinj. Department of geography, 135-144, Zagreb.

Faivre, S., 1994: Structural-geomorphological properties of the north Velebit and Senjsko bilo.- M.Sc. thesis (in Croatian). University of Zagreb, pp. 101.

Faivre, S., 2000: Landforms and tectonics of the Velebit mountain range (External Dinarides, Croatia).- $\mathrm{PhD}$ thesis. University of Zagreb \& Blaise Pascal University, Clermont II, pp. 360.

Faivre, S. \& J-F. Bocquet, 1999: Variation spatiale des contraintes tectoniques calculées a partir des dolines; Montagne de Velebit, Croatie (Spatial variation of stress orientations calculated from doline analysis, Velebit mountain rnage, Croatia).- Etudes de géographie physique, Travaux 1999 - Supplément $\mathrm{n}^{\circ}$ XXVIII CAGEP, Université de Provence, 83-88.

Faivre, S. \& P. Reiffsteck, 1999a: Spatial distribution of dolines as an indicator of recent deformations on the Velebit mountain range.- Géomorphologie: Relief, Processus, Environnement, 129-142.

Faivre, S. \& P. Reiffsteck, 1999b: Measuring strain and stress from sinkhole distribution, Example of the Velebit Mountain range, Dinarides, Croatia.- In: Beck, B.F., Pettit A.J. \& J.G. Herring (eds.) Proceedings of the Seventh Multidisciplinary Conference on sinkholes and the engineering and environmental impacts on karst $10^{\text {th }}-14^{\text {th }}$ April 1999, Harrisburg. A. A. Balkema, 25-30, Rotterdam, Brookfield,

Faivre, S. \& P. Reiffsteck, 2002: From doline distribution to tectonic movements. Example of the Velebit mountain range, Croatia.- Acta Carsologica, 31, 3, 139-154.

Faivre, S. \& M. Pahernik, 2007: Structural influences on the spatial distribution of dolines Island of Brač, Croatia.- Z. Geomorph. N.F., 51, 4, 487-503.

Ford, D.C. \& P.W. Williams, 2007: Karst Hydrogeology and Geomorphology.- John Wiley \& Sons, pp. 562, Chichester.

Fürst-Bjeliš, B., Lozić, S. \& D. Perica, 2001: Man and the environment in the central Velebit area - Baške Oštarije and surroundings.- Acta Geographica Croatica, 35, 111-132.
Fürst-Bjeliš, B. \& S. Lozić, 2006: Environmental impact and change on the Velebit Mountain, Croatia: and outline of the periodization.- In: Armiero, M. (ed.) Environmetal Stories from the Mediterranean World $\left(19^{\text {th }}-20^{\text {th }}\right.$ centuries $12^{\text {th }}-13^{\text {th }}$ September 2003., Napoli, Italy.. Consiglio Nazionale delle Richerce, Istituto di Studi sulle Società del Mediterraneo, 127-139, Napoli.

Gams, I., 1978: The polje: The problem of definition.- Z. Geomorph. N.F., 22, 2, 170-181.

Gams, I., 1991: System of adapting littoral Dinaric Karst to agrarian land use.- Geografski zbornik, 31, 5-106.

Gams, I., 2000: Doline morphogenetic processes from global and local viewpoints.- Acta Carsologica, 29, 2, 123-138.

Gerrard, J., 1992: Soil geomorphology. An integration of pedology and geomorphology.- Chapman \& Hall, pp. 269, London.

Glavičić, M., 1995: Pregled prapovijesnih naslaziša na primorskom obronku Velebit (The review of the historical finds on the coastal slope of the Mountain Velebit).- In: Tvrtković, N. (ed.) Paklenički zbornik, Vol.1, Simpozij povodom 45.godišnjice NP Paklenica, $19^{\text {th }}-22^{\text {th }}$ October 1994, Starigard-Paklenica. Naša djeca offset tisak, 215-222, Zagreb.

Gluščević, S., 1995: Podmorska topografija velebitskog primorja u Antici (Underwater topography of the Velebit coastline in ancient Greek and roman times).- In: Tvrtković, N. (ed.) Paklenički zbornik, Vol.1, Simpozij povodom 45.godišnjice NP Paklenica, $19^{\text {th }}-22^{\text {th }}$ October 1994, Starigard-Paklenica. Naša djeca offset tisak, 237-243, Zagreb.

Gračanin, M., 1931: Pedološka istraživanja Senja i bliže okolice (Pedological investigation of Senj and its surroundings).- Glasnik za šumske pokuse, 3, 5-75.

Horvat, I., 1949: Nauka o biljnim zajednicama (Learning on plant communities).- Nakladni zavod Hrvatske, pp. 434, Zagreb.

Hoyk, E., 1999: Investigations of the vegetation and soil in the dolinas of Mecsek Mountains, South Hungary.- Acta Carsologica, 28, 1, 105-113.

Joret, G. \& J. Hebert, 1955: Contribution à la détermination du besoin des sols en acide phosphorique.- $A n$ nales Agronomiques, 2, 233-299.

Kozličić, M., 1995: Atlas, kartografski spomenici hrvatskog Jadrana.- AGM, pp. 391, Zagreb.

Lovrenčak, F., 1977: Prsti v vrtačah Slovenije (Soil cover of the doline in Slovenia).- In: Vasović, M., (ed.) Zbornik 10. jubilarnog Kongresa geografa Jugoslavi$j e, 15^{\text {th }}-20^{\text {th }}$ September 1976, Beograd, Serbia. Savez geografskih društava Jugolsavije i Srpsko geografsko društvo, 443-449, Beograd. 
Magaldi, D. \& U. Sauro, 1982: Landforms and soil evolution in some karstic areas of the Lessini Mountains and Monte Baldo (Verona, Northern Italy).- Geogr. Fis. Dinam. Quat., 5, 82-101.

Mamužić, P., Milan, A., Korolija, B., Borović, I., \& Ž. Majcen, 1969: Main geological map, Rab, 1:100 000.IGI, Zagreb.

Marković, M., 1993: Descriptio Croatie.- Naprijed, pp. 371, Zagreb.

Meneghel, M. \& U. Sauro, 2006: Dolines of karstic and periglacial origin in the high mountain karst of Pale di San Martino plateau (Dolomites).Z.Geomorph.N.F., 50, 63-76.

Metson, A.J., 1956: Methods of chemical analysis for soil survey samples.- New Zealand Soil Bureau Bulletin, $12,102-103$.

Mihljević, D., 1995: Relief reflection of structural reshaping during the recent tectonically active stage, in the north-western part of the outer Dinarides mountain range.- Acta Geogr. Croatica, 30, 5-16.

Munsell Soil Color Charts, 1994: Munsell Color.- pp. 28, New Windsor, NY (USA).

Nedved, B., 1995: Srednje i južno velebitsko podgorje u Rimsko doba (Central and southern foothills of the Mount Velebit in the Roman times).- In: Tvrtković, N. (ed.) Paklenički zbornik, 1, Simpozij povodom 45. Godišnjice NP "Paklenica". NP Paklenica, pp. 223-228, Starigrad-Paklenica.

Nicod, J., 1967: Recherches morphologiques en Basse Provence calcaire.- Ophrys, pp. 557, Gap.

Nicod, J., 2003a: Understanding environmental problems in Dinaric karst.- Dela, 20, 27-41.

Nicod, J., 2003b: Les karsts Dinariques paysages et problèmes.- Karstologia Mémoires, 10, pp.183, Ljubljana

Pahernik, M., 1998: Utjecaj klime i reljefa na intenzitet površinske korozije karbonata gorske skupine Velike Kapele (Climate and relief influence on the carbonate surface corrosion intensity in the velika Kapela mountain gropue).- Acta Geographica 33, 46-58.

Perica, D., 1998: The karst geomorphology of the Velebit mountain range.- Unpublished $\mathrm{PhD}$ thesis (in Croatian). University of Zagreb, pp. 258.

Perica, D. \& N. Buzjak, 2001: Contact karst of Southern Velebit (Croatia).- Acta Carsologica, 30, 2, 25-40.

Perica, D., Lozić, S. \& I. Mrak, 2002a: Periglacijalni reljef na području Velebita (Periglacial Relief in Velebit Mountain Area).- Geoadria, 7, 1, 5-29.

Perica, D., Bognar, A. \& S. Lozić, 2002b: Geomorphological features of the Baške Oštarije karst polje.- Geoadria, 7, 2, 23-34.
Perica, D. \& D. Orešić, 1997: Prilog poznavanju klimatskih obilježja Velebit (Contribution on knowledge of the Velebit Mt. climate properties).- Acta Geographica Croatica, 32, 45-68.

Pfeffer, K-H., 1995: Karstresearch - a traditional science involving recent applied tasks.- Acta Geogr. Szegediensis, 34, 7-24.

Prelogović, E., 1975: Neotektonska karta SR Hrvatske (Neotectonic map of the Republic of Croatia).Geol. vjesnik, 28, 97-108.

Prelogović, E., 1989: Neotektonski pokreti u području Sjevernog Velebita i dijela Like (Neotectonic movmenets in Northern Velebit and Lika).- Geol. vjesnik, 42, 133-147.

Prelogović, E., 1995: Geološka struktura Velebita (Geological structure of Mount Velebit).- In: Tvrtković, N. (ed) Paklenički zbornik, 1, Simpozij povodom 45. Godišnjice NP "Paklenica". NP Paklenica, pp. 49-54, Starigrad-Paklenica.

Rogić, V., 1958: Le versant littoral du Velebit, Travaux de l'institut de géographe Université de Zagreb. 2. pp. 114.

Rubriche delle ville del Contado Superiore di Zara del pubblico perito C. Faventini, relative al catastro 1709, 1709. Tomo primo. Katastici Dalmacije $n^{\circ} .6$, Zadar State Archives.

Salomon, J-N., 2000: Précis de Karstologie.- Presses universitaires de Bordeaux, pp. 250, Bordeaux.

Sauro, U., 2003: The dolina: emblematic and problematic karst landform.- Dela, 20, 43-60.

Sauro, U., 2004: Closed Depressions.- In: Culver, D.C. \& W.B. White (eds.) Encyclopedia of Caves. Elsevier, pp. 108-122, Amsterdam.

Sauro, U., Ferrarese, F., Francese, R., Miola, A., Mozzi, P., Rondo., G.Q., Trombino, L., \& G. Valentini, 2009: Doline fills - case study of the faverghera plateau (Venetian pre-Alps, Italy).- Acta Carsologica, 38, 1, 51-63.

Sokač, B., Nikler, L., Velić, J. \& P. Mamužić, 1974: Main geological map, Gospić, 1:100 000.- IGI, Zagreb.

Thomas, G.W., 1982: Exchangeable cations.- In: Page, A.L. (ed.) Methods of soil Analysis, Agronomy, 9, 154-157, Madison.

Urushibara, K., 1976: The Mediterranena red soils in the three regions of the Yugoslavian Karst.- Geografski vestnik, 48, 123-135.

Urushibara, K., 1981: Regional variation of the Mediterranean red soils of Yugoslavia.- Erdkunde, 35, 1, $1-12$. 
Velić, I. \& J. Velić, 2009: Od morskih plićaka do planine (From Marine Shallows to the Mountain: Geological Guidebook through the Northern Velebit National Park).- Javna Ustanova Nacionalni park Sjeverni Velebit, pp. 143, Krasno.

Velić, I., Vlahović, I., Tišljar, J., Sremac, J. \& D. Matičec, 2006: Clastic-carbonate deposits of Middle-Upper Triassic (Ladinian-Norian).- In: Menichetti, M. \& D. Mencucci (eds.) Adria 2006 International Geological Congress on the Adriatic Area, Field trip Guide, $19^{\text {th }}$ $20^{\text {th }}$ June 2006, Urbino. Instituito di Science della Terra, Universita di Urbino, 54-55, Urbino

Vranković, A., 1973: Main pedological map Senj 1. 1: 50 000.- Sveučilište u Zagrebu, Agronomski fakultet, Zavod za pedologiju, Zagreb.
Vranković, A.,1974: Main pedological map Senj 3. 1: 50 000.- Sveučilište u Zagrebu, Agronomski fakultet, Zavod za pedologiju, Zagreb.

Vrbek, B. \& I. Pilaš, 2007: Prilog poznavanju tala Štirovače na Velebitu (Contribution on knowledge of Štirovača soils on Velebit).- Rad. Šumar. inst. Jastrebar.- 42, 2, 155-166.

Zaninović, M., 1980: Antička naselja ispod Velebita (Antique settelements along the Velebit Mt. foothills).Senjski zbornik, 8, 187-196.

White, W.B., 1988: Geomorphology and Hydrology of karst terrains.- Oxford University Press, pp. 464, New York. 